\title{
ANALISIS FINANCIAL USAHA TANI SAWI (Studi pada Petani Sawi di Kampung Jaifuri Distrik Skanto Kabupaten Keerom)
}

\author{
Daniel Dawan \\ dawandaniel31@yahoo.com ${ }^{1}$
}

'Dosen Fakultas Ekonomi dan Bisnis Universitas Cenderawasih

\begin{abstract}
Abstraksi:
Tujuan Penelitian ini adalah Untuk menganalisis tingkat pendapatan petani sawi di Kampung Jaifuri. Metode penelitian yang penulis gunakan adalah Penelitian Kualitatif dan Kuantitatif yang mana dengan maksud untuk memperkuat data penelitian. Penulis menggunakan teknik total sampling, maka sampel dalam penelitian adalah 10 orang petani. Hasil penelitian menunjukkan bahwa : (1) Hasil rata - rata dari 5 Informan pada biaya tetap Rp. 100.000, biaya variabel yaitu Rp. 506.000, dan volume penjualan usaha tani sawi di Kampung Jaifuri per satu kali panen Rp. 3.000.000. (2) Rata-rata tingkat pendapatan petani per satu kali panen yaitu Rp. 2.394.000. merupakan hasil rata-rata dari 5 (lima) responden penelitian selaku petani sawi di Kampung Jaifuri. (3) Rata-rata tingkat kelayakaan usaha tani sawi di Kampung Jaifuri adalah 4,62 berada pada kategori layak. Atau petani bisa mendapatkan keuntungan dari usaha tani yang dijalankan.
\end{abstract}

Kata Kunci : Financial, Usata Tani Sawi, Kampung Jaifuri

\section{PENDAHULUAN}

\section{A. Latar Belakang}

Sebuah usaha tani tentunya dimaksudkan untuk mendapatkan peningkatan hasil pendapatan petani sesuai dengan pendapat (Mubyarto, 1989:39) yang mengatakan pendapatan petani sebagai sasaran awal dalam pembanguan pertanian, hanya mungkin dicapai apabila diperoleh keuntungan yang maksimal dari kegiatan usahatani yang diselenggarakan. Dalam berusahatani yang baik, setiap petani dapat menghitung usahataninya. Pendapatan menjadi sasaran utama dalam mendorong suatu pengembangan kegiatan usahataninya (Mubyarto, $1989 ; 39$ ).

Sebuah hasil pendapatan akan terlihat dengan jelas apabila petani mengetahui teknik menganalisis finansial dari usahataninya seperti yang diungkapkan oleh Gray, 2002, yang menyatakan bahwa Analisis finansial lebih menekankan pada aspek 'input output' pada penerimaan dan pengeluaran yang sebenarnya. Dengan demikian pada analisis ini, variabel harga yang dipakai adalah data harga real. Analisis finansial adalah penting untuk mengetahui posisi proyek pada tahun tahun tertentu, apakah proyek defisit atau sebaliknya dalam keadaan yang menguntungkan (Gray, 2002).

Usahatani dikatakan efektif bila petani atau produsen dapat mengalokasikan sumberdaya yang mereka miliki (yang kuasai) sebaik-baiknya, dan dikatakan efesien bila pemanfaatan sumberdaya tersebut menghasilkan keluaran (output) yang melebihi masukan (input). Penelitian tentang analisis finansial ini penting dilakukan karena dapat menggambarkan apakah usahatani sayuran ini memberi keuntungan atau tidak, dengan cara membandingkan biaya dan penerimaan dalam suatu proses produksi. Selain itu, tujuan dari analisa finansial ini adalah untuk memaksimumkan keuntungan atau meminimumkan biaya serta mencari informasi tentang keragaman suatu usahatani yang dilihat dari berbagai aspek. Kajian berbagai aspek ini sangat penting karena setiap macam tipe usahatani pada setiap macam skala usaha serta lokasi tertentu berbeda satu sama lain, karena hal tersebut memang ada perbedaan dalam karakteristik yang dipunyai pada usahatani yang bersangkutan.

Hasil temuan penulis selama melakukan observasi awal di lokasi penelitian yaitu di Kampung Jaifuri adalah sebagai berikut :

1) Permasalahan yang sering dihadapi para pengusaha (petani) di Kampung Jaifuri dalam budidaya sawi khususnya dan sayuran sawi pada umumnya adalah fluktuasi harga, serangan hama dan penyakit tanaman serta sifat alami sayuran yang harus dikonsumsi dalam bentuk segar dan segera dijual setelah dipanen, sehingga dibutuhkan perlakuan khusus dan penanganan yang baik agar usahatani berhasil dalam arti mampu menghasilkan keuntungan bagi petani. 
2) Referensi dan data-data keberhasilan usahatani sayuran sawi masih merupakan hal yang hampir tidak pernah dijadikan acuan oleh petani dalam melaksanakan usahataninya, selain karena ketersediaannya yang tidak terjangkau petani juga karena data-data tersebut hanya ada dalam arsip lembaga atau instansi terkait.

3) Kendala yang dihadapai oleh petani sawi di kampung jaifuri adalah rendahnya harga sawi di pasar. Menurut petani di daerah penelitian, harga jual sawi yang diterima oleh petani yaitu $\mathrm{Rp} 60.000$ per $10 \mathrm{~kg}$, artinya harga jual sawi tersebut Rp 6000 per kg. Harga ini tergolong masih rendah jika di bandingkan dengan harga jual sawi dipedagang besar yaitu mencapai 8.000 sampai 10.000 per kg. Rendahnya harga tersebut menyebabkan pendapatan yang diterima oleh petani juga menjadi rendah. Pendapatan yang diterima oleh petani berkisar antara 1.0000 .000 sampai 2.000 .000 per bulan.

Penelitian penulis ini penting dilakukan dan bermanfaat bagi para petani di Kampung Jaifuri. Dimana agar para petani dapat menganalisis finansial dari sayuran yang mereka produksi apakah mendukung dari segi pendapatan atau malah merugikan bagi petani. Sehingga petani tidak lagi mengalami kerugian dalam keputusan petani melakukan kegiatan pertaniannya.

Penelitian penulis mereplikasi penelitian sebelumnya yang dilakukan oleh Wanda Arun (2012) yang berjudul Analisis Finansial Usahatani Sawi, Studi Kasus: Kelurahan Terjun, Kecamatan Medan Marelan. Perbedaan penelitian penulis dengan penelitian terdahulu adalah pada Lokasi Penelitian dimana penelitian terdahulu dilakukan di Kelurahan Terjun, Kec. Medan Marelan sedangkan penelitian penulis dilakukan di Kampung Jaifuri, Distrik Skanto, Provinsi Papua. Selain itu juga ada perbedaan lagi pada tahun penelitian dimana penelitian terdahulu dilakukan pada tahun 2012 sedangkan penulis melakukan penelitian pada tahun 2017.

Berdasarkan uraian diatas maka penulis melakukan penelitian dengan memberikan judul "Analisis Financial Usahatani Sawi" (Studi pada Petani Sawi di Kampung Jaifuri Distrik Skanto Kabupaten Keerom).

\section{B. Rumusan Masalah}

Adapun rumusan masalah sebagai berikut:

1. Berapa besar biaya tetap, biaya variabel, dan volume penjualan usaha tani sawi di Kampung Jaifuri per satu bulan?

2. Bagaimana tingkat pendapatan petani sawi di Kampung Jaifuri per satu bulan?

3. Bagaimana tingkat kelayakan usaha tani sawi secara finansial di Kampung Jaifuri?

\section{METODE PENELITIAN}

\section{A. Lokasi Penelitian}

Adapun waktu pelaksanaan penelitian adalah pada tanggal 2 s/d 7 September 2017. Penelitian ini dilakukan di kampung Jaifuri Distrik Skanto Kabupaten Keerom.

\section{B. Definisi Operasional}

1. Analisis finansial adalah untuk mengetahui posisi proyek pada tahun - tahun tertentu, apakah proyek defisit atau sebaliknya dalam keadaan yang menguntungkan (Gray, 2002)

2. Pendapatan adalah hasil yang diperoleh petani dalam usahatani selama satu tahun yang dapat diperhitungkan dari hasil penjualan atau pertukaran hasil produksi yang dinilai dalam rupiah berdasarkan harga per satuan berat dalam pemungutan hasil. (Gutiyana (2004),

3. Biaya Tetap adalah biaya yang jumlah totalnya tetap tidak berubah dalam rangka output tertentu, tetapi untuk semua satuan produksi akan berubah-ubah sesuai dengan perubahan produksi. (S.Munawir, 2002:155)

4. Biaya Variabel adalah biaya yang jumlah totalnya akan naik turung sebanding dengan hasil produksi atau volume kegiatan, tetapi untuk setiap satuan produksi akan tetap. (S. Munawir, 2002:185)

5. Usahatani adalah Suatu kegiatan pertanian rakyat yang terhimpun dari berbagai sumber daya alam.

\section{Jenis dan Sumber Data}

Adapun jenis dan sumber data sebagai berikut :

\section{Jenis Data}

a. Data kuantitatif

Data yang berbentuk angka atau bilangan. Sesuai dengan bentuknya, data kuantitatif dapat diolah atau dianalisis menggunakan teknik perhitungan matematika atau statistika. 


\section{b. Data kualitatif}

Data bukan dengan angka-angka tetapi dengan cara menggabungkan berbagai informasi yang dapat dipercayai untuk menjawab atau menjelaskan suatu permasalahan yang ada, yaitu tentang profil usahatani

\section{Sumber Data} sawi. (Sumber Kuntjaraningrat, 1999:30).

a. Data primer

Data yang diambil secara langsung dari petani yang mendukung dalam penelitian. Data primer dapat berupa karakteristik petani, penggunaan biaya produksi, tingkat pendapatan, tingkat kelayakan usahatani. Secara teknis dapat dilakukan dengan cara wawancara kepada petani selaku responden dan pihak - pihak yang berkaitan dengan penelitian, serta dilakukan dengan cara observasi yaitu pengamatan secara langsung terhadap objek penelitian.

b. Data sekunder

Data yang diperoleh dengan cara mengutip data laporan maupun dokumen dari lembaga atau instansi yang ada hubugannya dengan penelitian, dalam hal ini adalah Badan Pusat Statistik (BPS) serta dinas pertanian dan melalui media online. Secara teknis data sekunder dapat dilakukan dengan cara pencatatan.

\section{Populasi dan Sampel}

1. Populasi

Somantri dan Muhidin, (2006: 62) menyatakan: "Populasi merupakan keseluruhan elemen, atau unit elementer, atau unit penelitian, atau unit analisis yang memiliki karakteristik tertentu yang dijadikan sebagai objek penelitian." Yang menjadi populasi dari penelitian ini adalah 10 petani sawi di Kampung Jaifuri Distrik Skanto Kabupaten Keerom.

2. Sampel

Unit sampling dalam penelitian ini adalah petani sayuran sawi di daerah keerom. Dasar pengambilan sampel adalah pendapat dari Arikunto (2004: 134) menyatakan "apabila subjeknya kurang dari 100, lebih baik diambil semua sehingga penelitiannya merupakan penelitian populasi. Tetapi jika jumlah subjeknya besar dapat diambil antara $10-$ $15 \%$ atau $20-25 \%$ atau lebih". Dengan demikian, jumlah sampel yang diambil / digunakan sebanyak 5 orang.

\section{E. Teknik Pengumpulan Data}

Adapun teknik pengumpulan data yang penulis gunakan dalam penelitian ini adalah :

1. Studi Lapangan

Studi lapangan adalah beberapa tahapan penulis dalam rangka pengumpulan data penelitian yang dilaksanakan pada lokasi penelitian, diantaranya adalah :

a. Observasi, yaitu pengumpulan data yang dilakukan dengan melakukan pengamatan langsung. Atau bisa dikatakan peneliti mengadakan pengamatan secara langsung terhadap gejala atau objek yang diteliti selama penelitian berlangsung.

b. Wawancara, teknik ini dilakukan untuk pengumpulan data primer berdasarkan daftar pertanyaan yang telah dipersiapkan terlebih dahulu. Atau bisa dikatakan dalam teknik ini penulis berusaha mengumpulkan informasi dengan mengajukan pertanyaan secara lisan dan kontak lansung dengan cara tatap muka antara si pencapai informasi dengan sumber informasi

2. Studi Pustaka

Studi kepustakaan merupakan metode pengumpulan data yang dilakukan dengan mempelajari buku-buku atau literatur-literatur yang berhubungan dengan masalah atau topik penelitian.

3. Dokumentasi

Sebuah cara yang dilakukan untuk menyediakan dokumen-dokumen dengan menggunakan bukti yang akurat dari pencatatan sumber-sumber informasi khusus dari karangan/tulisan, wasiat, buku, undang-undang dan sebagainya. 


\section{F. Metode Analisa Data}

Teknik Analisa data dalam penelitian ini adalah menggunakan :

\section{Analisa Kualitatif}

Penggunaan analisa kualitatif dimaksud untuk mempertajam dan sekaligus memper kaya analisis kualitatif. Dalam Analisa kualitatif tersebut bisa berupa: jumlah penduduk, komposisi jumlah penduduk, komposisi mata pencarian, komposisi tingkat pendidikan masyarakat, jumlah anak-anak terlantar, jumlah sarana umum, tempat-tempat ibadah, sumber daya alam, tingkat curah hujan, dan sebagainya (Burbam bungin,2003,84). Analisa kualitatif yang akan dilakukan adalah untuk menganalisa:

2. Analisa Kuantitatif

Pengukuran atau pengkajian terhadap keadaan yang sebenarnya dalam populasi yang dalam bentuk angka, analisa kuantitatif menggunakan beberapa formula sebagai berukut.

a) Analisis Laba / Rugi

Rumus Laba / Rugi :

Penjualan

BiayaVariabel ..................

\begin{tabular}{ll}
\hline Konstribusi Margin .............. & Rp.xxxx \\
Biaya Tetap .................... & Rp.xxxx \\
\hline Laba Bersih ..................... & Rp.xxxx
\end{tabular}

(Estu Rahayu dan Nur Berlina V.A, 1999;91)

b) Analisis R/C Ratio

Penulis menggunakan metode analisis financial yaitu R/C yang dirumuskan sebagai berikut :

$R / C=\frac{T R}{T C}$

Dimana :

$\mathrm{TR}=$ Total Revenue (total penerimaan)

$\mathrm{TC}=$ Total Cost $($ total biaya)

Bila $R / C \geq 1$, maka usahatani tersebut dikatakan layak

Bila $\mathrm{R} / \mathrm{C}<1$, maka usahatani tersebut dikatakan tidak layak.

\section{HASIL DAN PEMBAHASAN}

\section{A. Analisis Pendapatan}

Dalam menganalisis financial dari petani sawi di Kampung Jaifuri distrik skanto, maka penulis melakukan wawancara kepada 5 informan penelitian, yang mana mereka merupakan para petani sawi di lingkungan Kampung Jaifuri. Kemudian hasil data yang penulis peroleh selama berada di lokasi penelitian adalah sebagai berikut :

\section{Modal investasi Dalam Faktor Produksi}

Petani dalam menggarap lahannya memerlukan beberapa peralatan seperti cangkul, sabit dan hand sprayer, untuk mengetahui beberapa harga peralatan yang di miliki dan digunakan petani di dalam mengusahakan lahannya dapat dilihat pada tabel di bawah ini.

Tabel 1. Daftar Peralatan Yang Digunakan Dalam UsahaTani Sawi

\begin{tabular}{|c|c|c|c|c|c|c|c|}
\hline \multirow{2}{*}{ Petani } & \multicolumn{2}{|c|}{ Cangkul } & \multicolumn{2}{|c|}{ Sabit } & \multicolumn{2}{|c|}{ Hand Sprayer } & \multirow{2}{*}{ Total } \\
\hline & $Q$ & P/Unit & $Q$ & P/Unit & Q & P/Unit & \\
\hline 1 & 3 & $\operatorname{Rp} 70.000$ & 5 & Rp 40.000 & 2 & Rp 380.000 & $\mathrm{Rp} \quad 1.170 .000$ \\
\hline 2 & 3 & $\operatorname{Rp} 70.000$ & 5 & Rp 40.000 & 2 & Rp 380.000 & $\begin{array}{ll}\mathrm{Rp} & 1.170 .000\end{array}$ \\
\hline 3 & 3 & $\operatorname{Rp} 70.000$ & 4 & Rp 40.000 & 1 & Rp 415.000 & 785.000 \\
\hline 4 & 3 & $\operatorname{Rp} 70.000$ & 5 & $\operatorname{Rp~} 40.000$ & 2 & Rp 380.000 & $\begin{array}{ll}\mathrm{Rp} & 1.170 .000 \\
\end{array}$ \\
\hline 5 & 3 & $\operatorname{Rp} 80.000$ & 4 & Rp 52.000 & 3 & Rp 380.000 & $\mathrm{Rp} \quad 1.588 .000$ \\
\hline
\end{tabular}

Sumber : Data Diolah, 2019 
Dari tabel diatas dapat dilihat bahwa harga cangkul, sabit dan hand sprayer dari setiap petani ada yang sama dan ada yang berbeda harganya, hal ini dikarenakan para petani membeli peralatan tersebut tidak pada satu tempat atau toko.

\section{Perhitungan Biaya Depresi / Penyusutan Peralatan}

Adapun metode depresiasi yang digunakan dalam metode depresiasi garis lurus (dengan asumsi nilai residu sama dengan 0 ) dengan rumus sebagai berikut :

$$
\text { Biaya Depresiasi }=\frac{\text { Harga perolehan }- \text { Nilai residu }}{\text { Umur ekonomis }}
$$

Maka untuk responden pertama :

$$
\begin{aligned}
\text { Biaya Depresiasi per empat bulan } & =\frac{\mathrm{Rp} 1.200 .000}{12} \\
& =100.000 \text { per bulan }
\end{aligned}
$$

Untuk mengetahui berapa besar biaya depresiasi dari peralatan-peralatan yang digunakan oleh petani, selama 1 tahun dapat dilihat pada tabel di bawah ini.

\section{Tabel 2. Biaya Depresiasi Peralatan Untuk Satu Kali Masa Panen} Untuk 1 Kali Masa Panen

\begin{tabular}{|c|c|c|c|}
\hline Petani & Nilai Peralatan (Rp) & $\begin{array}{c}\text { Umur } \\
\text { Ekonomis }\end{array}$ & $\begin{array}{c}\text { Biaya penyusutan } \\
\text { per bulan (Rp) }\end{array}$ \\
\hline 1 & $\operatorname{Rp~} 1.200 .000$ & 12 bln & 100.000 \\
\hline 2 & $\operatorname{Rp~} 1.200 .000$ & 12 bln & 100.000 \\
\hline 3 & $\operatorname{Rp~} 800.000$ & 12 bln & 66.666 \\
\hline 4 & $\mathrm{Rp} 1.200 .000$ & $12 \mathrm{bln}$ & 100.000 \\
\hline 5 & $\mathrm{Rp} 1.600 .000$ & $12 \mathrm{bln}$ & 133.333 \\
\hline
\end{tabular}

Sumber : Data Diolah, 2019

Dari tabel diatas telah diketahui biaya depresi dari 5 (lima) informan petani sawi di kampung jaifuri dimana terlihat bahwa biaya depresi yang dikeluarkan oleh para petani sawi berbeda - beda tergantung dari jumlah investasi peralatan yang dikeluarkan oleh petani.

\section{Biaya Operasional}

Biaya operasional dari para petani sawi di Kampung Jaifuri merupakan jumlah biaya yang dikeluarkan dari masa tanam sampai panen, meliputi biaya tetap, dan biaya variabel dimana biaya tetap merupakan penyusutan peralatan dan biaya tidak tetap merupakan biaya selama proses tanam hingga panen berlangsung. Untuk mengidentifikasi masalah pertama dianalisis dengan menggunakan analisis biaya produksi yang dirumuskan sebagai berikut:

$\mathrm{TB}=\mathrm{BV}+\mathrm{BT}$

$$
\begin{aligned}
& \text { Dimana : } \\
& \text { TB }=\text { Total Biaya }(R p) \\
& \text { BV }=\text { Biaya Variabel }(\mathrm{Rp}) \\
& \text { BT }=\text { Biaya Tetap }(R p)
\end{aligned}
$$

Berikut dibawah ini merupakan rincian biaya operasional dari 5 responden penelitian 
Tabel 3. Biaya Operasional Petani Sawi di Kampung Jaifuri

\begin{tabular}{|c|c|c|c|c|c|c|c|c|c|}
\hline \multirow{2}{*}{ Jenis } & \multicolumn{3}{|c|}{ Resp 1 (600m2) } & \multicolumn{3}{c|}{ Resp 2 (1 Hektar) } & \multicolumn{3}{c|}{ Resp 3 (200m2) } \\
\cline { 2 - 10 } & $\mathrm{Q}$ & $\mathrm{P}$ & Total & $\mathrm{Q}$ & $\mathrm{P}$ & Total & $\mathrm{Q}$ & $\mathrm{P}$ & Total \\
\hline $\begin{array}{c}\text { Biaya } \\
\text { Variabel }\end{array}$ & & & & & & & & & \\
\hline Bibit & 5 & 5,000 & 25,000 & 8 & 5,000 & 40,000 & 2 & 5,000 & 10,000 \\
\hline Pupuk & 10 & 15,000 & 150,000 & 15 & 15,000 & 225,000 & 4 & 15,000 & 60,000 \\
\hline Pestisida & 3 & 50,000 & 150,000 & 6 & 50,000 & 300,000 & 2 & 50,000 & 100,000 \\
\hline T.Kerja & 1 & 150,000 & 150,000 & 1 & 200,000 & 200,000 & 1 & 100,000 & 100,000 \\
\hline Biaya Tetap & & & & & & & & & \\
\hline Depresiasi & 100,000 & 100,000 & & 100,000 & 100,000 & & 66,666 & 66,666 \\
\hline \multicolumn{2}{|c|}{ Total } & $\mathbf{5 7 5 , 0 0 0 , -}$ & & & $\mathbf{8 6 5 , 0 0 0 , -}$ & & & $\mathbf{3 3 6 , 6 6 6 , -}$ \\
\hline
\end{tabular}

Sumber : Data diolah, 2019

Berdasarkan tabel diatas terlihat bahwa Total Biaya Operasional dari reponden 1 sebesar Rp. 575.000 , Responden 2 sebesar Rp. 865.000, Responden 3 sebesar Rp. 336.000. perbedaan biaya operasional tiap responden dipengaruhi oleh jumlah biaya variabel dan biaya tetap yang berbeda-beda.

Tabel 4. Biaya Operasional Petani Sawi di Kampung Jaifuri

\begin{tabular}{|c|c|c|c|c|c|c|}
\hline \multirow{2}{*}{ Jenis } & \multicolumn{3}{|c|}{ Resp 4 (600m2) } & \multicolumn{3}{c|}{ Resp 5 (800m2) } \\
\cline { 2 - 7 } & $\mathrm{Q}$ & $\mathrm{P}$ & Total & $\mathrm{Q}$ & $\mathrm{P}$ & Total \\
\hline Biaya Variabel & & & & & & \\
\hline Bibit & 5 & 5,000 & 25,000 & 6 & 5,000 & 30,000 \\
\hline Pupuk & 10 & 15,000 & 150,000 & 11 & 15,000 & 165,000 \\
\hline Pestisida & 3 & 50,000 & 150,000 & 4 & 50,000 & 200,000 \\
\hline T.Kerja & 1 & 150,000 & 150,000 & 1 & 150,000 & 150,000 \\
\hline Biaya Tetap & & & & & & \\
\hline Depresiasi & & 100,000 & 100,000 & & 133,333 & 133,333 \\
\hline Total & & & $\mathbf{5 7 5 , 0 0 0}$ & & & $\mathbf{6 7 8 , 3 3 3}$ \\
\hline
\end{tabular}

Sumber : Data diolah, 2019

Berdasarkan tabel diatas terlihat bahwa Total Biaya Operasional dari reponden 4 sebesar Rp. 575.000 , Responden 6 sebesar Rp. 678.333. Perbedaan biaya operasional tiap responden dipengaruhi oleh jumlah biaya variabel dan biaya tetap yang berbeda-beda.

Tabel 4.6.

Ringkasan Biaya Operasional Petani Sawi

Kampung Jaifuri Distrik Skanto

\begin{tabular}{|c|c|c|c|}
\hline Petani & $\begin{array}{c}\text { Biaya Variabel / } \\
\text { (BV) }\end{array}$ & $\begin{array}{c}\text { Biaya Tetap } \\
\text { (BT) }\end{array}$ & $\begin{array}{c}\text { Total Biaya } \\
\text { (TB) }\end{array}$ \\
\hline 1 & 475.000 & 100.000 & 575.000 \\
\hline 2 & 765.000 & 100.000 & 865.000 \\
\hline 3 & 270.000 & 66.666 & 366.666 \\
\hline 4 & 475.000 & 100.000 & 575.000 \\
\hline 5 & 545.000 & 133.333 & 678.333 \\
\hline \multicolumn{3}{|c|}{ Jumlah } & $\mathbf{3 . 0 2 9 . 9 9 9}$ \\
\hline \multicolumn{3}{|c|}{ Rata-rata } & 607.000 \\
\hline
\end{tabular}

Sumber : Data diolah, 2019

Perhitungan :

Responden $1:$ :Rp. $475.000+$ Rp. $100.000 \quad=575.000$

Responden 2 :Rp. $765.000+$ Rp. $100.000 \quad=865.000$ 


$\begin{array}{lll}\text { Responden } 3 & \text { :Rp. } 270.000+\text { Rp. } 66.666 & =366.666 \\ \text { Responden } 4 & \text { :Rp. } 475.000+\text { Rp. } 100.000 & =575.000 \\ \text { Responden 5 } & \text { :Rp. } 545.000+\text { Rp. } 133.333 & =678.333\end{array}$

Dari Tabel diatas terlihat bahwa total biaya operasional dari 5 responden berbeda - beda. Seperti contoh responden 1 dengan biaya variabel Rp. 475.000 dan Biaya Tetap Rp. 100.000 sehingga Total Biaya adalah Rp. 575.000. kemudian dari tabel diatas juga diketahui bahwa total biaya produksi dari 5 responden adalah Rp.3.029.000 dengan rata-rata biaya produksi Rp. 607.000

Biaya produksi sejatinya merupakan uang yang dikeluarkan dalam proses produksi, seperti pengolahan lahan, biaya perawatan, pemupukan, pemanenan dan transportasi penjualan. Yang mana dalam produksi ada 2 hal yang digunakan untuk dapat mengukur total biaya produksi, yaitu biaya variabel yang mana merupakan biaya tidak tetap atau sewaktu - waktu dapat berubah, seperti harga bahan bakar, harga pupuk, beberapa daftar harga tersebut mempengaruhi besar kecilnya biaya produksi dalam satu musim tanam hingga panen. Dan yang kedua adalah biaya tetap yaitu biaya yang tetap atau tidak berubah seperti contoh upah kerja karyawan yang mana dikeluarkan setiap bulan tidak pernah berubah.

Penulis menemukan hasil bahwa di Kampung Jaifuri petani sawi mengeluarkan biaya operasional berkisar antara Rp. $366.000 \mathrm{~s} / \mathrm{d}$ Rp. 865.000. perbedaan jumlah harga biaya produksi dari para petani terlihat dari skala penanaman, dimana petani yang menanam dalam skala luas lahan kecil maka biaya produksi akan rendah, kemudian jika petani menaman sawi dalam skala besar atau di lahan yang luas, maka sudah pasti ongkos atau biaya produksi akan semakin besar pula.

Hasil ini membuktikan bahwa biaya produksi sangat dipengaruhi oleh harga bahan pendukung seperti pupuk, perawatan, pemanenan dan transportasi. Apabila beberapa harga tersebut naik, maka sudah tentu petani sawi di Kampung Jaifuri akan membutuhkan biaya yang besar dalam satu kali musin tanam hingga panen. Penentuan biaya tidak tetap dan biaya tetap oleh para petani sangat dibutuhkan atau harus secara tepat dan hati - hati, karena kalau salah menentukan biaya maka yang terjadi adalah kerugian bagi para petani sawi di Kampung Jaifuri.

\section{Volume Penjualan para Petani Sawi di Kampung Jaifuri}

Untuk melihat volume produksi tiap bulan maupun per tahun dan tingkat penjualan per tahun tiap responden dapat dilihat pada tabel 4.4 berikut ini :

Tabel 6. Volume Penjualan dalam 1 Kali Masa Panen

\begin{tabular}{|c|c|c|c|c|c|}
\hline Petani & Luas Lahan & $\begin{array}{l}\text { Jumlah } \\
\text { Produksi / } 1 \\
\text { Bendeng }\end{array}$ & $\begin{array}{l}\text { Jumlah } \\
\text { Produksi }\end{array}$ & $\begin{array}{l}\text { Harga / } \\
\text { lkat }\end{array}$ & $\begin{array}{c}\text { Volume } \\
\text { Penjualan }\end{array}$ \\
\hline R.1 & $600 \quad \mathrm{~m} 2$ & 100 lkat & 600 lkat & 5,000 & $3,000,000$ \\
\hline R.2 & $1,000 \quad \mathrm{~m} 2$ & 100 Ikat & $1000 \mathrm{lkat}$ & 5,000 & $5,000,000$ \\
\hline R.3 & $200 \quad \mathrm{~m} 2$ & $100 \quad$ lkat & 200 lkat & 5,000 & $1,000,000$ \\
\hline R.4 & $600 \quad \mathrm{~m} 2$ & 100 lkat & 400 lkat & 5,000 & $2,000,000$ \\
\hline R.5 & $800 \quad \mathrm{~m} 2$ & 100 lkat & 800 lkat & 5,000 & $4,000,000$ \\
\hline \multicolumn{5}{|c|}{ Total } & $15,000,000$ \\
\hline \multicolumn{5}{|c|}{ rata-rata } & $3,000,000$ \\
\hline
\end{tabular}

Sumber: Data Diolah 2019

Rumus perhitungan Volume Penjualan: Volume Penjualan = Jumlah Produksi $\mathrm{x}$ harga jual

Pada tabel diatas menunjukkan bahwa besarnya volume penjualan responden berbeda - beda tergantung dari volume produksi petani dalam 1 kali masa panen yang akan mempengaruhi total penjualan petani. Secara keseluruhan total rata - rata penjualan petani per 1 kali masa panen dari 5 responden adalah Rp. $\mathbf{3 . 0 0 0 . 0 0 0 . ~}$ 


\title{
5. Analisis Tingkat Pendapatan Petani Sawi di Kampung Jaifuri.
}

Untuk mengidentifikasi masalah kedua analisis dengan menggunakan analisis pendapatan yaitu menggunakan rumus Laba/Rugi yang dirumuskan sebagai berikut:

\author{
Laba/Rugi \\ Kontribusi Margin = Penjualan - Biaya Variabel \\ Laba Bersih = Kontribusi Margin - Biaya Tetap
}

Berikut merupakan perhitungan laba rugi dari petani sawi dalam 1 kali masa panen

Tabel 7. Perhitungan Rugi Laba / Rugi dalam 1 Kali Masa Panen

\begin{tabular}{|c|c|c|c|c|c|}
\hline Petani & Penjualan & $\begin{array}{c}\text { Biaya } \\
\text { Variabel }\end{array}$ & $\begin{array}{c}\text { Kontribusi } \\
\text { Margin }\end{array}$ & Biaya tetap & Laba \\
\hline R.1 & $3,000,000$ & 475,000 & $2,525,000$ & 100,000 & $2,425,000$ \\
\hline R.2 & $5,000,000$ & 765,000 & $4,235,000$ & 100,000 & $4,135,000$ \\
\hline R.3 & $1,000,000$ & 270,000 & 730,000 & 66,666 & 663,334 \\
\hline R.4 & $2,000,000$ & 475,000 & $1,525,000$ & 100,000 & $1,425,000$ \\
\hline R.5 & $4,000,000$ & 545,000 & $3,455,000$ & 133,333 & $3,321,667$ \\
\hline \multicolumn{7}{|c}{ Jumlah } & $\mathbf{1 1 , 9 7 0 , 0 0 1}$ \\
\hline \multicolumn{7}{|c}{ Rata-rata } \\
\hline
\end{tabular}

Dari tabel diatas terlihat bahwa pendapatan 5 petani sawi di Kampung Jaifuri berbeda - beda. Kemudian diketahui bahwa jumlah pendapatan dari 5 responden adalah Rp.11.970.000 dengan rata-rata pendapatan sebesar Rp. 2.394.000.

Pendapatan petani sawi di Kampung Jaifuri dipengaruhi oleh dua faktor total penerimaan kotor dan total biaya produksi. Dimana jika total penerimaan kotor tinggi dan biaya produksi rendah maka petani sawi akan memperoleh keuntungan atau pendapatan yang besar. Terjadi sebaliknya jika total penerimaan kotor itu rendah namun biaya produksi tinggi maka hasil keuntungan atau pendapatan petani akan rendah.

Yang terjadi pada para petani sawi di Kampung Jaifuri adalah pendapatan bersih yang diterima petani sebanding dengan biaya produksi yang dikeluarkan. Atau bisa diartikan total biaya produksi jauh dibawah total penerimaan kotor. Yang artinya petani memperoleh keuntungan yang cukup lumayan dari bertani sawi.

Ini membuktikan bahwa bertani sawi harus mempertimbangkan biaya produksi dan penerimaan kotor, karena kedua hal tersebut merupakan penentu atau akhir dari sebuah usaha produksi. Pendapatan yang besar akan diperoleh jika biaya produksi tidak melampaui total penerimaan kotor dari usaha produksi yang dijalankan, dalam hal ini bertani sawi.

\section{Analisis Tingkat Kelayakan Usaha Tani Sawi Secara Finansial di Kampung Jaifuri. (R/C rasio)} berikut :

Untuk mengidentifikasi masalah ketiga menggunakan metode analisis financial yaitu R/C yang dirumuskan sebagai

$$
R / C=\frac{T R}{T C}
$$

Dimana :

$\mathrm{TR}=$ Total Revenue (total penerimaan)

$\mathrm{TC}=$ Total Cost $($ total biaya $)$

Bila $R / C \geq 1$, maka usahatani tersebut dikatakan layak

Bila $R / C<1$, maka usahatani tersebut dikatakan tidak layak. 
Tabel 7.

Analisis Tingkat Kelayakan Usaha Tani Sawi Secara Finansial di Kampung Jaifuri Distrik Skanto

\begin{tabular}{|c|c|c|c|c|}
\hline Responden & $\begin{array}{c}\text { Total Penerimaan } \\
\text { (TR) }\end{array}$ & $\begin{array}{c}\text { Total Biaya } \\
\text { Produksi } \\
\text { (TC) }\end{array}$ & $\begin{array}{c}\text { Rasio Kelayakan } \\
\text { Usaha } \\
\text { (R/C) }\end{array}$ & $\begin{array}{c}\text { Status } \\
\text { L / TL }\end{array}$ \\
\hline Responden 1 & 3.000 .000 & 575.000 & 5,22 & Layak \\
\hline Responden 2 & 5.000 .000 & 865.000 & 5,78 & Layak \\
\hline Responden 3 & 1.000 .000 & 366.666 & 2,73 & Layak \\
\hline Responden 4 & 2.000 .000 & 575.000 & 3,48 & Layak \\
\hline Responden 5 & 4.000 .000 & 678.333 & 5,90 & Layak \\
\hline \multicolumn{2}{|r}{} & Rata-rata & $\mathbf{4 , 6 2}$ & Layak \\
\hline
\end{tabular}

Sumber : Data diolah, 2019

Dari tabel diatas terlihat bahwa rasio kelayakan usaha dari 5 para petani sawi di Kampung Jaifuri berbeda - beda. Kemudian juga diketahui bahwa rata-rata rasio kelayakan usaha petani sawi berada ada point 4,62 yang artinya layak karena lebih dari nilai standar yaitu 1 (satu).

Analisis Financial merupakan sebuah usaha untuk melihat kelayakan dari usaha yang dijalankan. Dalam penelitian ini penulis hendak meneliti tentang finansial dari para petani sawi di Kampung Jaifuri dimana ada dua hal yang penulis lihat untuk dapat memperoleh data finansial dari para petani sawi di Kampung Jaifuri, yaitu Total Penerimaan dan Biaya produksi dari hasil bagi antara dua item tersebut akan diperoleh angka rasio kelayakan usaha.

Standar penilaian kelayakan usaha adalah jika nilai rasio < 1 maka usaha dinyatakan tidak layak dan sebaliknya jika rasio kelayakan usaha $>1$ maka usaha dinyatakan layak. Pengertian layak dan tidak layak disini adalah layak artinya usaha yang dilakukan oleh petani mendapatkan keuntungan yang sepadan. Dan berlaku sebaliknya tidak layak artinya total penerimaan petani sawi tidak dapat mendukung total biaya pengeluaran, yang artinya petani sawi mendapatkan kerugian sehingga usaha tidak layak. Penulis melihat yang terjadi pada petani sawi di Kampung Jaifuri adalah rasio kelayakan usaha dari 5 responden penelitian berkisar antara 3 sampai dengan 5 yang artinya usaha atau kegiatan bertani sawi layak untuk dijalankan. Layak dijalankan berarti usaha bertani sawi yang dilakukan petani dapat memperoleh keuntungan yang sesuai harapan petani.

\section{PENUTUP}

\section{A. Simpulan}

Dari hasil penelitian dan pembahasan pada bab sebelumnya, maka dapat disimpulkan sebagai berikut:

1. Hasil rata - rata dari 5 responden pada biaya tetap Rp. 100.000 , biaya variabel yaitu Rp. 506.000 , dan volume penjualan usaha tani sawi di Kampung Jaifuri per satu kali panen Rp. 3.000.000.

2. Rata-rata tingkat pendapatan petani per satu kali panen yaitu Rp. 2.394.000. merupakan hasil ratarata dari 5 (lima) responden penelitian selaku petani sawi di Kampung Jaifuri

3. Rata-rata tingkat kelayakaan usaha tani sawi di Kampung Jaifuri adalah 4,62 berada pada kategori layak. Atau petani bisa mendapatkan keuntungan dari usaha tani yang dijalankan.

\section{B. Saran}

1. Ditujukan kepada petani sawi di Kampung Jaifuri, hasil penelitian menunjukkan bahwa rasio kelayakan usaha lebih dari 1 artinya berstatus layak. Maka usaha ini dapat terus dijalankan dan tentu harus menguasai teknik analisa finansial usaha agar tidak mengalami kerugian dalam usahanya..

2. Ditujukan kepada Universitas Cenderawasih, diharapkan pada tahun berikutnya dapat menerjunkan mahasiswa praktik ke lokasi lain yang berhubungan dengan kegiatan pertanian. Agar pengetahuan mahasiswa di bangku perkuliahan dapat diaplikasikan kepada masyarakat petani sehingga pengetahuan petani tentang memanajemen usaha meningkat.

3. Ditujukan kepada Penelitian Selanjutnya, diharapkan hasil penelitian yang penulis lakukan dapat menjadi referensi atau masukan bagi peneliti selanjutnya dan dapat menambahkan faktor - faktor lain yang digunakan dalam menganalisis finansial sebuah usaha petanian ataupun industri lain. 


\section{DAFTAR PUSTAKA}

[1]. Ahmad, Hiskia. 2001. Kimia Larutan. Bandung: Citra Aditia Bakti.

[2]. Arikunto, Suharsimi.,2004. Prosedur Penelitian: Suatu pendekatan Praktek. Bandung: Rineka Cipta.

[3]. Ating Somantri \& Sambas Ali Muhidin., 2006, Aplikasi Statistika Dalam Penelitian. Bandung : Penerbit Pustaka Setia.

[4]. Daniel. M. 2002. Pengantar Ekonomi Pertanian. Bumi Aksara. Jakarta.

[5]. Gray, C, Panyaman S., Lien K.S., P.F.L. Maspaitella dan R.C.G. Varley. 2002. Pengantar Evaluasi Proyek. Gramedia, Jakarta.

[6]. Gustiyana, H. 2004. Analisis Pendapatan Usahatani untuk Produk Pertanian. Salemba empat: Jakarta.

[7]. Hanifah dalam Gusti Renita Yuanda.2012.Analisis Usahatani Buah Naga Daging Super Merah (Hylocereus costaricensis) Sampai Tahun Ke-4 di Kabupaten Padang Pariaman:Kabupaten Padang Pariaman.27 hal.

[8]. Hernanto, Fadholi.1994.IImu Usahatani.Penebar Swadaya: Jakarta.

[9]. Haryanto, Eko.,Tina Suhartini.,Estu Rahayu.,Hendro Sunarjono. 2007. Sawi dan Selada. Penebar Swadaya, Jakarta

[10]. Hernanto. F., 2006. IImu Usahatani. Penebar Swadaya. Jakarta

[11]. lin Hastuti Hartoyo.2008. "Analisis Faktor-faktor yang mempengaruhi dividend payout ratio pada perusahanManufaktur di bursa efek Indonesia" Tesis. Universitas Diponegoro

[12]. Mardikanto. 2009. Sistem Penyuluhan Pertanian. Sebelas Maret University Press. Surakarta.

[13]. Mubyarto 1989, pengantar ekonomi pertanian. LP3ES.jakarta

[14]. Munandar, Utami S.C. 1977. Creativity and Education, Disertasi Doktor U.I. Jakarta : Universitas Indonesia.

[15]. Meta sianturi, Diana chalil, Thomson sebayang,2007. Departemen agribisnis fakultas pertanian Universitas sumatra utara " analsis usahatani sayuran"

[16]. Ridwan, Dewi Hastuti, Rossi Prabowo,"2006. Analisis pendapatan usahatani kangkung darat tradisional"

[17]. Soetriono, Suwandari Anik, Rijanto. 2006. Pengantar Ilmu Pertanian. Malang : Bayumedia.

[18]. Soekarwati 1995, Analisis Usahatani. UI. Press Jakarta

[19]. Soekartawi, 2002. Analisis Usahatani. UI. Press. Jakarta

[20]. Suratiyah, K. 2011. IImu Usahatani.Bogor: Penebar Swadaya.

[21]. Wanda Aruan, Iskandarini, Mozart " analisis financial usahatani sawi"

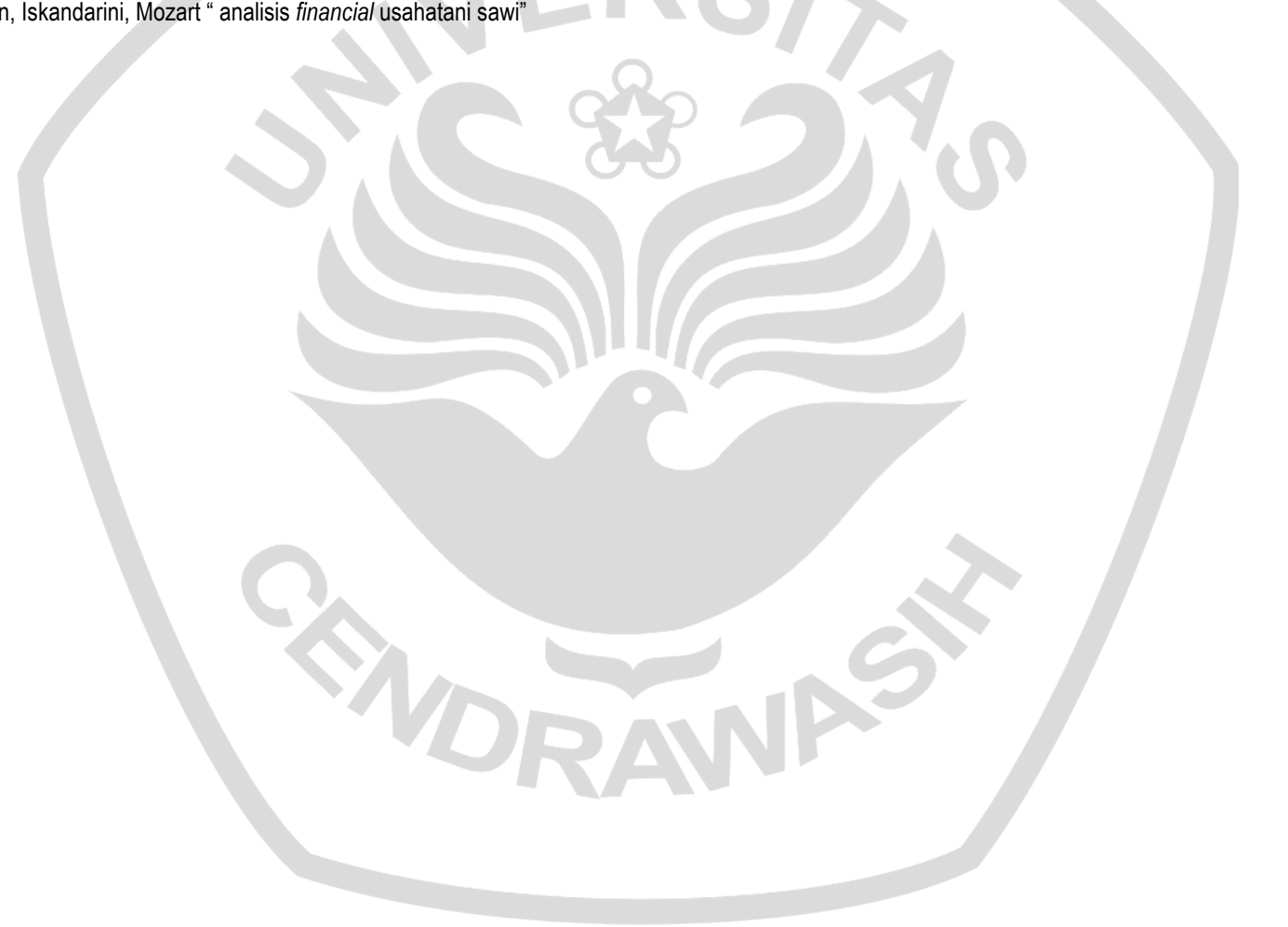

